\title{
SOME MANAGEMENT CHALLENGES FOR FOOD COMPANIES IN THE REPUBLIC OF SERBIAAND BOSNIA AND HERZEGOVINA
}

\author{
Filip Đoković, ${ }^{1}$ Radovan Pejanović, ${ }^{2}$ Jelena Đorđević Boljanović3 ${ }^{3}$ Gordana Dobrijević, \\ Miloš Mojsilovićs ${ }^{5}$ Đurđica Jojić Novakovićc
}

\begin{abstract}
Summary
This paper aims to explore controlling, one of the key management functions, and autonomy at work, a determinantof employee control. Another purpose of this research is to examine the differences in autonomy or, more precisely, to find out to what degree autonomy among nonmanagers may affect creativity, innovation and business performance of an organization. The research was performed in food companies in the Republic of Serbia and Bosnia and Herzegovina. The data collected via a questionnaire were analysed by the SPSS statistical software.Five-level Likert scale was used to rate the responses. The main findingsshow that employees in food companies in Serbia perceive a higher level of autonomy than their counterparts in Bosnia and Herzegovina, and that the level of autonomy varies among different departments, the highest being in marketing and sales.
\end{abstract}

Key words: management, controlling, autonomy at work, food industry, employees, Serbia, Bosnia and Herzegovina.

JEL: Q15, Q18, E20.

1 Fillip Đoković, Ph.D., Assistant Professor, Singidunum University, Faculty of Health, Legal and Bussines Studies, Železnička StreetNo. 5, Phone: +381 14292 610, E-mail: fdjokovic@singidunum.ac.rs

2 Radovan Pejanović, Ph.D.Full Professor, University of Novi Sad, Agricultural Faculty, DositejaObradovica Square no. 8, 21000 Novi Sad, Phone: +381 216350 622, E-mail: pejanovic@uns.ac.rs

3 Jelena Đorđević Boljanović, Ph.D. Associate Professor, Singidunum University, Faculty of Business, Kumodraška Street No. 261a, Phone: +381 113094 094, E-mail: jboljanovic@ singidunum.ac.rs

4 Gordana Dobrijević, Ph.D. Associate Professor, Singidunum University, Faculty of Business, Kumodraška Street No. 261a, Phone: +381 113094 094, E-mail: gdobrijevic@ singidunum.ac.rs

5 Miloš Mojsilović, M.A., Ipsos Strategic Marketing, GavrilaPrincipa Street No. 8, Phone: +381 113284 075, E-mail: mojsilovic.milos@gmail.com

6 Đurđica Jojić Novaković, PhD student, Faculty of Hotels Managment and Tourism, University of Kragujevac, Vrnjačka Banja, Vojvođanska 5A Street, 36210 Vrnjačka Banja, Phone +381 603873 422, E-mail: djurdjica.jojic@gmail.com

EP 2018 (65) 1 (157-172) 


\section{Introduction}

Management is a United States term to describe an act of managing, that is, coordinating the elements and factors of production so as to serve the purposes of an organisation (Pejanović, 2012). There are five management functions: planning, organising, staffing, coordinating and controlling. Controlling is a managerial function designed to keep track of what has been done, and compare the performance with the existing standards. When problems occur, it's either the standards or the work to be done that needs to be changed. The five components of management are closely interrelated and open to change.

A fairly new concept in the development of global economy - knowledge economy has triggered a series of changes, affecting not only the way modern organisations are doing business, but also their organisational design and management structure, and even more so the way they interact with their consumers, competitors and partners in a shifting competitive business landscape. The complexities of modern companies, transforming their production and technology, as well as social responsibility, have also affected the design of a controlling system in the management process. The imperative of a permanent growth in economic efficiency, gauged by using a return on assets (ROA) ratio or another financial indicator, has been imposed on a company's managers.

Drucker argued back in 2005 that controlling was one of the key factors to shape management in a knowledge economy. This important management function is gaining prominence in the increasingly competitive markets, driven by a constant demand for growing efficiency in the use of resources, considerable cost cuts, cheaper yet improved services and products, rapid and permanent innovation to upgrade products and processes, the quick obsolescence of technologies and other explicit, organisational knowledge.

Control, or controlling, is a manager's effort to gauge, evaluate and compare actual achievements against those planed, in order to take corrective actions to address off-plan results (Krstić, 2012). The corrective actions are taken to tackle a negative variance, when a business or individual performance is off target. Controlling is a necessity, but under the modern concept of control, managers should not use it as a restraining tool, but rather a creative instrument to encourage and guide employees in reaching desired individual and work-related performance levels. Control is a steering mechanism for individuals to help them work towards their own life goals in the context of organisational objectives.

In the era of knowledge economy, managers should create a work environment, in which employees can unlock their potential in the most productive way, relying on their prior knowledge, professional competence and practical skills (Jovanović et al., 2010; Pejanović, 2001). In a decision-making process - particularly in the implementation stage and in fulfilling job requirements - one of the key mechanisms of employee control is to enable employees to practice autonomy in decision making and in meeting their job requirements. Autonomy implies freedom of thought and action, and a free decision making, encouraging creativity and innovativeness. 


\section{Theoretical Background}

In the operation of a company, it's possible and indeed necessary to control nearly all assignments, jobs, activities, processes, and most notably so, the resulting business performance. It's a necessity, because however competent and experienced managers might be, they can't predict with high probability the course a business operation might take in a near or distant future if exposed to a wide array of uncertainties and risks. Besides, the information needed to reach a decision is rarely known upfront, while there's a whole spectre of internal and external factors shaping the operation and growth of a company, which the management is equally unaware of.

There are three levels of control across an organisation, covering a) the company as a system, b) processes and activities, and c) operators (Pejanović, 2011; Milisavljević, 2012; Krstić, 2012, Đuričin et al., 2016). The organisational structure of control at the company level consists of the primary business functions that resources and competences are distributed against. On the other hand, departments can be composed of different smaller organisational units (plants, sections, services), and it's necessary to control their respective results and the performance of their operators as well. Likewise, a company can be viewed as a set of inter-functional business processes, whose competitiveness hinges of how successfully they are executed (Đoković et al., 2017). It is therefore necessary to monitor and control the processes and activities, as there's clearly a strong link between more effective business processes and company performance. The process control is expected to satisfy consumer needs by ensuring a quality process output, along with the efficient and effective execution of the process.

Company outputs involve different business processes, performed and streamlined by individuals (operators in the broadest sense of the term), fulfilling their job requirements. Accordingly, performance control implies so-called individual performance, too, as a separate level of performance. The performance of an individual includes his/ her work results, achievements, productivity, contribution, competence, knowledge, commitment, loyalty, etc. (Su et al. 2015; Krstić and Sekulić, 2013; Fletcher and Williams 1996). It's precisely the control of operators that's the central theme of the paper, as the research goal is to establish a relationship between controlling the company and the processes on the one hand, and the operator on the other.

A manager's control includes a set of activities that are key not only to successful business performance management in his/her organisation, but also to managing the performance of subordinates, lower-level managers and non-managers.

Autonomy on the job constitutes a very important feature at work (Breaugh, 1999; Aube et al., 2007), and it typically refers to a relationship between the management and employees. It's defined as the establishment of integrity, freedom and independence of employees in performing business activities and making decisions within the job description (Vanderfeesten and Reijers, 2006; Van Mierlo et al. 2006). 
In a number of studies, a link has been established between autonomy at work, individual performance and company results (Breaugh, 1985; Denton and Kleiman, 2001; Judge et al., 2001). In order to reach autonomy at work, employees should know their purpose in the company, and the way their results shape the overall business performance. Autonomy in the workplace is also another motivational factor for employees (Herzberg, 1968; Saragih, 2011). In framing autonomy at work, responsibility for planning and employee control deserves a special emphasis. The employee needs to be able to fully complete a job (a project, a task, etc.), as integrity in doing it is a motivation boost per se.

Autonomy largely increases job satisfaction. More complex jobs, which imply an increased level of responsibility, call for broader autonomy, too (Cooper and Locke, 2000). Aside from pre-set rules and procedures referring to a job, creativity, as a permitted decision-making space, plays an important role as well.

A global research by the Economist Intelligence Unit (Laserfriche and Economist Intelligence Unite, 2014) quoted more than two-thirds (68 per cent) of 227 corporate, education and government leaders as saying that a pressing need to increase efficiency, cut costs and manage risks had tightened centralised control in certain business units, departments and offices over the previous five years. At the same time, 57 percent of the respondents said that their organizations had delegated broad decision-making authority to business units, local or regional offices and other groups. A large number of the leaders (42 per cent) said that their organisations allowed for autonomy and performed controls at the same time. The same source suggests that in order to strike a balance between the two it's necessary to use information technologies to facilitate centralised control and autonomy alike, and to choose standardisation over centralisation.

Autonomy at work is a phenomenon that has drawn interest from theorists and practitioners involved in work efficiency management. Autonomy spans a broad spectre of advantages, from freedom in terms of the actual performance of a job, through flexible hours and workplace arrangements, to more developed forms of autonomy referred to in theory and practice as job crafting.

The results of a research by the University of Birmingham, involving 20,000 British employees, revealed that employees with broader autonomy at work reported positive effects on their wellbeing and a higher degree of job satisfaction. Having explored different forms of autonomy, the author, Daniel Wheatley, maintained in the 2017 study that there's a difference between "job control" and "schedule control". "Job control" referred to the job tasks and pace of work, and "schedule control" to the actual hours. Another peculiar finding is that the two types of control have different gender- and agerelated impacts. The positive effects on personal wellbeing notwithstanding, managers are still reluctant to offer a higher degree of autonomy to employees, preferring to solidify their primacy in control and ensure maximum effort from employees, the new piece of research has shown. 
In a bid to identify a better relationship between an employee and his/her job, job crafting has been defined as a set of physical and cognitive changes individuals make in relation to their task or relational boundaries of their work. The method allows individuals to adjust a job to themselves, their competences, proclivities, skills and motivation to do it properly. There are three ways to apply job crafting (Wrzesniewski and Dutton, 2001): task crafting, proactively changing the number, scope or type of tasks; relational crafting, allowing employees to change the quality and extent of interactions with others at work, and cognitive crafting, changing the way employees think about their work, or how they perceive their job tasks.

It's only together with the contextual factors of a working environment, such as support to autonomy at work, that the individual factors, job crafting included, can lead to employee wellbeing. Support to autonomy depends on a specific management style, requiring a manager open to new experiences, who's also able to understand and support different views by employees, and encourage an initiative on their part. The autonomy support is therefore necessary for the development of the individual factors, and only together can they create a motivating working environment.

The specific structure of business operations in the food industry makes employee control in the industry very particular as well. The tailored conditions surrounding food production have created clear-cut divisions within, based on the nature, time and location of different operations, very strict controls and clear boundaries between employees and managers. With this in mind, it's a challenge to find out how the organisational trend of blurring the strict boundaries and divisions affects controlling in food industry (Pejanović, 2013). Can the trend open new room for tighter control by employees, through autonomy and selfdetermination in doing a job, or rather soften the control they have over their job (Holt and Hvid, 2014). The research the abovementioned authors had carried out in two food companies revealed that in spite of scepticism about the change, employees were pleased to have an opportunity to plan their work and learn something new, which might be a primary driving force of change opening the industry's door to autonomy at work.

\section{Research Methodology and Hypothesis}

The subject of the study is the role of autonomy at work in employee control in food companies in Serbia and Bosnia and Herzegovina.

The purpose of the research is to analyse the level of autonomy on the job in the food companies, in order to find out to what degree autonomy at work can encourage innovation, initiatives, interpersonal relationships and individual performance.

The sample includes 192 employees in the Serbian and Bosnian companies. Their food production/processing portfolios include:

- Milling products;

- $\quad$ Fruit and vegetable juices;

- $\quad$ Milk processing and cheese production; 
- Meat processing and canning;

- $\quad$ Coffee and tea processing.

The research has covered 31 companies in Serbia, and another 30 in Bosnia and Herzegovina. These are active companies, with a positive financial result. The emphasis is on medium-sized and large companies that have reported income of at least EUR10 million over the past three years, with no fewer than 80 employees.

Table 1. Basic Information about the Research Subjects in Serbia and Bosnia and Herzegovina

\begin{tabular}{|c|c|c|c|}
\hline \multirow[b]{2}{*}{ QUESTION } & \multirow[b]{2}{*}{ CATEGORIES } & \multicolumn{2}{|c|}{ Respondents } \\
\hline & & SERBIA & $\begin{array}{c}\text { BOSNIA AND } \\
\text { HERZEGOVINA }\end{array}$ \\
\hline \multirow{2}{*}{ Gender } & Male & 54 & 55 \\
\hline & Female & 40 & 43 \\
\hline \multirow{4}{*}{ Age groups } & below 29 & 12 & 18 \\
\hline & $30-44$ & 47 & 32 \\
\hline & $45-65$ & 28 & 35 \\
\hline & over 65 & 7 & 13 \\
\hline \multirow{5}{*}{$\begin{array}{l}\text { E d u c a t i o n a } 1 \\
\text { qualification }\end{array}$} & Secondary education & 26 & 41 \\
\hline & College/university degree & 51 & 46 \\
\hline & Specialists & 9 & 5 \\
\hline & Master degree & 8 & 6 \\
\hline & $\mathrm{PhD}$ & 0 & 0 \\
\hline \multirow{7}{*}{$\begin{array}{l}\text { Organis ation a } 1 \\
\text { structure }\end{array}$} & Marketing and Sales & 16 & 16 \\
\hline & Production & 21 & 19 \\
\hline & Quality Department & 9 & 12 \\
\hline & Procurement & 18 & 19 \\
\hline & Finance & 11 & 12 \\
\hline & Human Resources & 14 & 17 \\
\hline & Legal Department & 5 & 3 \\
\hline
\end{tabular}

Source: The authors' own calculation

Most of the employees, as many as half of them, belong to the 30-44 age group (Table 1). The age structure in Bosnia and Herzegovina is somewhat different though, as it's dominated by the 45-65 age group. As for educational qualifications, most of the interviewed employees have a college/university degree, and most work in the procurement and $H R$ departments.

\section{Research Instrument}

The questionnaire incorporated 20 questions. Part 1 included four general questions, related to gender, age, educational qualifications and organisational structure. Part 2 consisted of 16 questions, referring to autonomy at work as a determinant of employee control. The authors used a Likert scale, offering a choice of five responses: 1-strongly disagree, 2-disagree, 3-neither agree nor disagree, 4-agree, 5-strongly agree. 
SPSS Statistics software, Version 19.0, has been used to process the sample and calculate descriptive statistics, i.e. the mean, median, and standard deviations. Aside from the descriptive statistics, the following methods of statistical analysis have been used: Preliminary statistical procedures (Explore); Correlation analysis (Spearman's Rho coefficient); Independent sample T-tests for comparing means; Scale reliability analysis (Alpha Crombach's coefficients).

Based on the research goal, the following hypotheses were tested:

H1. The realisation of innovation requires a higher degree of autonomy at work in decision making and task performance.

H2. There are differences in a degree of autonomy at work between decision making and task performance.

H3. There are differences in launching initiatives for change, depending on motivation and creativity.

H4. Better interpersonal relations exist in companies offering a higher degree of autonomy at work in decision making and task performance.

H5. A lower degree of autonomy in decision making and task performance has a negative effect on employees 'work results in each part of the organization.

\section{Research Results and Discussion}

The hypotheses have been tested with categorial variables, and the results presented in tables.

In the modern business world, innovation is a driver of competitive advantage. A company's management should follow the key trends in the industry neighbourhood, encouraging innovation at home. From this perspective, opportunities have been explored as to whether innovation and innovative processes are truly accepted, and if managers are aware of them (Table 2). The correlation coefficient referring to the questions indicative of the two phenomena is relatively low against the total sample size (0.34), but slightly higher in the group of Serbian respondents (0.52). In these two cases, the correlation has a statistical importance, too, as it's a statistical regularity, not a product of coincidence. Yet the coefficient is very low in Bosnia and Herzegovina (0.16), and it's not statistically significant, as $p=0.11$, i.e. over 0.05 , meaning that the hypothesis is accepted that the two phenomena in the Bosnian sample are statistically independent, and there's no correlation between them. 
Table 2. Correlation between the Arguments of Innovation in the Workplace and Autonomy at Work

\begin{tabular}{|l|l|l|l|l|l|}
\hline \multicolumn{1}{|c|}{ Method } & \multicolumn{1}{|c|}{ Variables } & $\begin{array}{c}\text { Statistical } \\
\text { Indicators }\end{array}$ & $\begin{array}{c}\text { Total } \\
\text { Sample }\end{array}$ & \multicolumn{1}{c|}{ Serbia } & $\begin{array}{c}\text { Bosnia and } \\
\text { Herzegovina }\end{array}$ \\
\hline $\begin{array}{l}\text { Spearman's } \\
\text { rho }\end{array}$ & $\begin{array}{l}\text { Autonomy at work in } \\
\text { relation to a decision to } \\
\text { introduce innovation in the } \\
\text { workplace }\end{array}$ & $\begin{array}{l}\text { Correlation } \\
\text { Coefficient }\end{array}$ & 0.34 & 0.52 & 0.16 \\
\cline { 3 - 7 } & Sig. (2-tailed) & 0.00 & 0.00 & 0.11 \\
\cline { 3 - 6 } & $\mathrm{N}$ & 192 & 94 & 98 \\
\hline
\end{tabular}

Source: Prepared by the authors based on data analysis in SPSS 19.0

When it comes to decision making, introducing innovation depends somewhat on a level of autonomy at work. To be more accurate, individual decisions alone cannot guarantee more permanent innovation, or expand it throughout the company. It is safe to say that the introduction of strategic innovation depends exclusively on the management, and that autonomy at work might be a determinant of control after the management has committed to operational innovation.

Autonomy at work is considered a tool for employee control. Depending on the job description and the sector, it's important to establish the intensity of control and decide to what degree to apply it, eventually gauging the impact it might have on employees' creativity and motivation.

As for the food industry in Serbia and Bosnia and Herzegovina, companies are not competitive enough (Jeremić et al., 2016; Bešić et al., 2015). The argument largely refers to their technological competitiveness, or rather the lack thereof, hinging on permanent innovation. Coupled with a low level of knowledge, it's impossible to expect a company to thrive technologically, which in turn leads to low employee productivity (Njegovan, Pejanović, 2015; Pejanović, Njegovan, 2013; Maksimović, Pejanović, Njegovan 2013; Bešić et al. 2014).

The differences in the level of autonomy in decision making and task performance have been explored in two ways (Table 3). It's important to note that integrity in decision making with a higher level of responsibility is implicit, and that the performance of a task suggests respect to the task-inherent rules and procedures. The authors have first compared the arithmetic mean inducing the level of autonomy in decision making (1-no autonomy, 5-full autonomy) and frequency, i.e. the existing level of control in different intervals.

The Kruskal-Wallis test, comparing the arithmetic mean between two or more independent samples, detected in the total sample statistically significant differences in the level of autonomy at work, depending on the existing levels of control - the more frequent the existing level of control, the lower the level of autonomy. For example, with daily controls, the average value of autonomy on this scale is mere 1.59. Conversely, biannual controls increase the autonomy average to 2.54 , growing to 3.14 with no control whatsoever. The statistically significant results have been reported in the Serbian sample as well (the p-value is less than 0.05), but in Bosnia and 
Herzegovina the significance level was larger than 0.05 (0.25). Besides, the arithmetic averages in the companies employing daily, weekly or monthly controls unveiled no particular regularities in the Bosnian sample, as opposed to the total sample and the Serbian sub-sample.

Table 3. The Control of Results, Autonomy in Decision Making and Task Performance

\begin{tabular}{|l|c|c|c|}
\hline \multicolumn{1}{|c|}{ Item } & \multicolumn{3}{c|}{ The Arithmetic Mean } \\
\hline Intensity of Control & Total Sample & Serbia & $\begin{array}{c}\text { Bosnia and } \\
\text { Herzegovina }\end{array}$ \\
\hline Daily & 1.59 & $/ 1$ & 2.14 \\
\hline Weekly & 2.09 & 1.90 & 2.28 \\
\hline Monthly & 1.87 & 1.72 & 2.07 \\
\hline Quarterly & 1.87 & 1.92 & 1.84 \\
\hline Biannual & 2.54 & 2.36 & 3.50 \\
\hline Not implemented & 3.14 & 4.16 & 2.73 \\
\hline $\begin{array}{l}\text { Statistical significance (Sig. } \\
\text { P<0.05) Kruskal-Wallis Test }\end{array}$ & $\mathrm{p}=0.00$ & $\mathrm{p}=0.00$ & $\mathrm{p}=0.25$ \\
\hline Mean Value & 2.03 & 1.83 & 2.22 \\
\hline
\end{tabular}

Source: Prepared by the authors based on data analysis in SPSS 19.0

The other way of argument testing is to use three questions about the impact of the existing level of control to create a separate total control scale first.

The reliability of the scale has been tested using Crombach's Alpha coefficient. It's fairly high (0.84), which indicates that the three individual questions follow the same direction, participating in the summary scale to a relevant degree. A correlation coefficient has been used to compare this scale with the one indicating the level of autonomy in decision making (Table 4). The scale has been used for the other hypotheses as well, testing the level of control under the name "control-total."

Table 4. Correlation between the Arguments of Autonomy at Work and Employee Control

\begin{tabular}{|c|l|l|r|r|r|}
\hline Methods & \multicolumn{1}{|c|}{ Variables } & \multicolumn{1}{c|}{$\begin{array}{c}\text { Statistical } \\
\text { Indicators }\end{array}$} & $\begin{array}{c}\text { Total } \\
\text { Sample }\end{array}$ & \multicolumn{1}{c|}{ Serbia } & $\begin{array}{c}\text { Bosnia and } \\
\text { Herzegovina }\end{array}$ \\
\hline \multirow{3}{*}{ Spearman's rho } & $\begin{array}{l}\text { Autonomy at work in relation } \\
\text { to decision making and } \\
\end{array}$ & $\begin{array}{l}\text { Correlation } \\
\text { Coefficient }\end{array}$ & 0.49 & 0.71 & 0.30 \\
\cline { 3 - 7 } & Sig. (2-tailed) & 0.00 & 0.00 & 0.01 \\
\cline { 2 - 7 } & $\mathrm{N}$ & 192 & 94 & 98 \\
\hline
\end{tabular}

Source: Prepared by the authors based on data analysis in SPSS 19.0

The authors are confident that there's a statistically significant, positive relationship between the secondary scale, indicating the existing level of control, and the scale indicating autonomy in decision making. The correlation is particularly high in the Serbian sub-sample, slightly lower in Bosnia and Herzegovina, reaching 0.49 in the total sample. Statistical significance has been confirmed at all three levels, meaning that with the growing perception that the existing level of control encourages creativity, motivation and innovation, the feeling of autonomy in decision making grows as well. 
Establishing viable controlling in companies does affect the motivation and creativity of employees (Guinot et al., 2014; Goris, 2007). In modern organizations, it's a challenge to establish exactly the type of control that would be an incentive for employees in terms of the quality of task performance (Chen and Chang, 2013). For the purposes of the research, a fairly firm and statistically significant correlation has been established between motivation, creativity and initiatives (Table 5). In other words, those who think that the existing levels of control have a positive impact on motivation and creativity, also tend to believe that the existing levels of control were conducive to launching initiatives as well.

Table 5. Correlation between the Arguments of the Impact of Control on Motivation, Creativity and Innovation in Task Performance

\begin{tabular}{|c|c|c|c|c|c|}
\hline Method & Variables & $\begin{array}{l}\text { Statistical } \\
\text { Indicators }\end{array}$ & $\begin{array}{c}\text { Total } \\
\text { Sample }\end{array}$ & Serbia & $\begin{array}{l}\text { Bosnia and } \\
\text { Herzegovina }\end{array}$ \\
\hline \multirow{3}{*}{$\begin{array}{l}\text { Spearman's } \\
\text { rho }\end{array}$} & \multirow{3}{*}{$\begin{array}{l}\text { The impact of control on } \\
\text { motivation and initiatives } \\
\text { for innovation in task } \\
\text { performance }\end{array}$} & $\begin{array}{l}\text { Corre la tion } \\
\text { Coefficient }\end{array}$ & 0.59 & 0.73 & 0.45 \\
\hline & & Sig. (2-tailed) & 0.00 & 0.00 & 0.00 \\
\hline & & $\mathrm{N}$ & 192 & 94 & 98 \\
\hline \multirow{3}{*}{$\begin{array}{l}\text { Spearman's } \\
\text { rho }\end{array}$} & \multirow{3}{*}{$\begin{array}{l}\text { The impact of control on } \\
\text { creativity and initiatives } \\
\text { for innovation in task } \\
\text { performance. }\end{array}$} & $\begin{array}{l}\text { Corre la ti o n } \\
\text { Coefficient }\end{array}$ & 0.61 & 0.75 & 0.46 \\
\hline & & Sig. (2-tailed) & 0.00 & 0.00 & 0.00 \\
\hline & & $\mathrm{N}$ & 192 & 94 & 98 \\
\hline
\end{tabular}

Source: Prepared by the authors based on data analysis in SPSS 19.0

Again, the correlation is the highest in the Serbian respondent group, over 0.70, it's comparably lower in the total sample, and the lowest in the Bosnian sample. Significance is under 0.05 in all three samples, indicating no correlation whatsoever.

Interpersonal relationships are important for creating favourable working conditions, resulting in the maximum performance from employees. To a degree, job satisfaction depends on interpersonal relations, too. Having explored the correlation between autonomy at work and the role interpersonal relationships have in employee satisfaction, the authors have found it to be very low though, barely reaching the borderline level of statistical significance. It means that good interpersonal relations are not the result of a higher level of autonomy at work, when it comes to decision making (Table 6). In the total sample, correlation was 0.19, in Serbia 0.28, and mere 0.15 in Bosnia and Herzegovina.

Table 6. Correlation between the Arguments of Autonomy at Work in Decision Making and Employee Satisfaction with Interpersonal Relations

\begin{tabular}{|l|l|l|r|r|r|}
\hline Methods & \multicolumn{1}{|c|}{ Variables } & \multicolumn{1}{c|}{$\begin{array}{c}\text { Statistical } \\
\text { Indicators }\end{array}$} & $\begin{array}{c}\text { Total } \\
\text { Sample }\end{array}$ & Serbia & $\begin{array}{c}\text { Bosnia and } \\
\text { Herzegovina }\end{array}$ \\
\hline \multirow{2}{*}{$\begin{array}{l}\text { Spearman's } \\
\text { rho }\end{array}$} & $\begin{array}{l}\text { Decision making and } \\
\text { employee satisfaction } \\
\text { with interpersonal } \\
\text { relations }\end{array}$ & $\begin{array}{l}\text { C o r r e la t i o n } \\
\text { Coefficient }\end{array}$ & 0.19 & 0.28 & 0.15 \\
\cline { 3 - 6 } & Sig. (2-tailed) & 0.06 & 0.06 & 0.14 \\
\cline { 2 - 6 } & $\mathrm{N}$ & 192 & 94 & 98 \\
\hline
\end{tabular}

Source: Prepared by the authors based on data analysis in SPSS 19.0 
As every food company included in the research consists of organisational parts (departments), a relationship has been studied between employees' autonomy at work and their performance, and it turns out to be different in different departments (Table 7).

Table 7. Correlation between the Argument of Autonomy at Work and Employee Performance in Different Departments

\begin{tabular}{|l|r|r|}
\hline Department & Correlation Coefficient & $\begin{array}{c}\text { Statistical Significance } \\
(\text { Sig. } \mathbf{p}<\mathbf{0 . 0 5})\end{array}$ \\
\hline Marketing and Sales & -0.41 & 0.01 \\
\hline Production & 0.27 & 0.08 \\
\hline Quality Department & 0.19 & 0.40 \\
\hline Procurement & -0.18 & 0.29 \\
\hline Finance & -0.11 & 0.61 \\
\hline Human Resource Management & -0.35 & 0.05 \\
\hline
\end{tabular}

Source: Prepared by the authors based on data analysis in SPSS 19.0

A low level of autonomy at work has a negative effect on employee performance, particularly in the Marketing and Sales, as a moderate and statistically significant negative correlation $(-0.41)$ has been recorded. The higher the level of autonomy at work, the lower the tolerance of employees to performance measurement methods is. No such correlation has been recorded in other departments.

Business operations in the Marketing and Sales do involve pronounced creativity and innovativeness in employees. Accordingly, the results show that there's a direct link between a higher degree of autonomy at work and improved performance, expected to produce more effective promotional strategies and a boost to the sales at the end of the day. Yet for the sales in a food company to grow, the competitiveness of the final product needs to be handled first.

\section{Conclusions}

Given the specific characteristics of the food industry, autonomy at work is becoming increasingly important in managerial decision making. Balancing between autonomy and control shapes a new environment that allows employees to perform their work tasks timely and creatively.

As the companies included in the research share similar business climate, working conditions and product diversification, the occurrences in the two states are very much alike. The results have shown that employees in Serbia's companies enjoy a higher degree of autonomy in performing their tasks and improving business performance.

Based on the research results and differences between employees in Serbia and Bosnia and Herzegovina, a strong conclusion has been drawn that the level of education and the length of service largely determinate the capacity of the employee to respond to the requirements of a food company. More precisely, longer-term employees, who in the Serbian companies typically have a university degree as well, enjoy a higher rank in the company and a higher degree of autonomy at work. 
Likewise, a level of autonomy at work has different effects on the level of employee motivation, which the research results have confirmed, too. Lower motivation levels in Bosnia and Herzegovina's companies raise a number of questions over the key motivation drivers. There are certainly many reasons behind the result, but the one the study has revealed is the correlation between lower levels of education and job dissatisfaction.

Different departments in a food company display varying degrees of autonomy at work. The results have confirmed, without any significant variables between the Serbian and Bosnian employees, that the highest level of autonomy at work has been recorded in the marketing and sales departments. It is safe to say that a decision to award them a higher level of autonomy can encourage creativity - one of the intrinsic qualities of the two departments - and that it's fairly easy to justify by the short and long-term goals of their organisational sections. Frequent changes in marketing may provide a mental stronghold in the minds of the managers, allowing them to offer these departments more autonomy at work, particularly in creating activities and tasks for employees.

What also makes this paper specific is the choice of the research sample, and a drive to explore autonomy at work as a phenomenon. The research themes in earlier papers largely revolved around top managers in different fields, whereas this one has focused on employees instead. Autonomy at work is analysed outside management structures, and it's actually the reflection of the autonomy the management has provided for that's being examined here.

The research work for this paper has also raised questions related to employee perception of autonomy, and the valorisation of efficient decisions by the management of a food company. The objective is to view autonomy at work as a balance between flexibility and control, against the backdrop of key management processes. Autonomy in the workplace can't be the result of an ad hoc campaign, bound to produce shortlived and often very negative effects in a company.

Controlling as a tool to ensure a free flow of knowledge and successful implementation of knowledge management programs should strike a balance between autonomy at work and employee control. This, in a way, upholds the basic postulates of knowledge management - a high degree of autonomy in the workplace and in pre-set models of behaviour, allowing the creativity and innovativeness of employees to come to the fore, with control to provide economic justification and purpose for their activities in a company.

The results of the research, involving employees in the food industry of Serbia and Bosnia and Herzegovina, have produced a general conclusion that a degree of autonomy exists in human resource management, but that a systematised framework in managerial decision making doesn't. The level of autonomy at work is higher in Serbia than in Bosnia and Herzegovina. The results don't apply to the general employed population though, largely because the food industry is very specific, and the questionnaire used in the research echoes its specific features. 
The research presented in the paper outlines one of the many ways to explore different methods and management frameworks pertaining to employee management in the food industry. The complexity of a delicate balance between flexibility and control in companies draws more attention than before. Taking into account the limitations inherent to the research, including the economic and social situation in the Western Balkans, the authors feel that every effort should be made to launch a new set of studies looking into autonomy at work, in order to make it possible for business decisions to be more conducive to the success of food companies and other organisations.

\section{Literature}

1. Aube, C., Rousseau, V., Morin, E. (2007). Perceived organizational support and organizational commitment: The moderating effect of locus of control and work autonomy. Journal of Managerial Psychology, Vol. 22, Vol. 5, pp. 479-495.

2. Bešić, C., Bogetić, S., Ćoćkalo, D., Đorđević, D. (2015). Uloga GLOBAL G.A.P.-a u unapređenju konkurentnosti poljoprivredno-prehrambene industrije, Ekonomika poljoprivrede, Vol. 62, No. 3, pp. 583-597.

3. Bešić, C., Ćoćkalo, D., Đorđević, D., Bogetić, S. (2014). Analiza aspekata konkurentnostiprehrambene industrije u Republici Srbiji. Ekonomika poljoprivrede, Vol. 61, No. 3, pp. 647-659.

4. Breaugh, J. A. (1985). The measurement of work autonomy. Human Relations, Vol. 38, pp. 551-570.

5. Breaugh, J.A. (1999). Further investigation of the work autonomy scales: two studies. Journal of Business and Psychology, Vol. 13 No. 3, pp. 357-373.

6. Cooper, C., Locke, E. (2000). Industrial and Organizational Psychology (9780631209928). Blackwell Publishers Ltd.

7. Denton, D., Kleiman, L. (2001). Job tenure as a moderator of the relationship between autonomy and job satisfaction. Applied H.R.M Research, Vol. 6, No. 2, pp. 105-114. Available herehttp:/www.laserfiche.com/ECMBlog/index.php/article/ economist-intelligence-unit-disciplined-autonomy-resolving-the-tension-betweenflexibility-and-control

8. Drucker, P. (2005). Upravljanje u novom društvu (86-7668-024-8). Adižes, Novi Sad.

9. Đoković, F., Pejanović, R., Mojsilović, M., Đorđević Boljanović, J., Plećić, K. (2017). Mogućnosti revitalizacije ruralnog turizma u funkcionisanju agrarnih zadruga. Ekonomika poljoprivrede. Vol. 64, No. 3, pp. 1115-1132.

10. Đuričin, D., Janošević, S., Kaličanin, Đ. (2016) Menadžment i strategija (978-86403-1468-8). CID Ekonomskog fakulteta, Beograd.

11. Fletcher, C. and Williams, R. (1996). Performance management, job satisfaction and organizational commitment. British Journal of Management, Vol. 7, No. 2, pp. 169-179.

12. Goris, J. (2007). Effects of satisfaction with communication on the relationship 
between individual - job congruence and job performance/satisfaction. Journal of Management Development, Vol. 26, No.8, pp.737-752.

13. Guinot, J., Chiva, R., Roca Puig, V. (2014). Interpersonal trust, stress and satisfaction at work: an empirical study. Personnel Review, Vol. 43, No. 1, pp. 96-115.

14. Herzberg, F. (1968). One more time: how do you motivate employees? Harvard Business Review, Vol. 46, No.1, pp. 53-62.

15. Holt, H., Hvid, H. (2014). Management and employee control in current industrial work. Nordic Journal of Working Life Studies, Vol. 4, No. 3, pp. 57-78.

16. Jeremić, Z., Milojević, M., Terzić, I. (2016). Poslovne performanse 15 najvećih izvoznika iz prehrambeno-prerađivačke industrije u periodu 2008-2014.godina, Ekonomika poljoprivrede, Vol. 63, No. 3, pp. 943-957.

17. Jovanović, P., Mišković, V., Šobajić, V., Rudić, T. (2010). Upravljanje znanjem i revolucija znanja. Industrija, Vol. 39, No. 1, pp. 217-226.

18. Judge, T., Thoresen, C., Bono, J., Patton, G. (2001). The job satisfaction - job performance relationship: A qualitative and quantitative review. Psychological Bulletin, Vol. 127, pp. 376-407.

19. Krstić B., Sekulić V. (2013). Upravljanje performansama preduzeća (978-86-6139-1392). Ekonomski fakultet, Niš.

20. Krstić, B. (2012). Uloga strategijske kontrole u unapređenju poslovnih performansi (97886-6139-050-0). Ekonomski fakultet, Niš.

21. Laserfricheand Economist Intelligence Unit (2014). Disciplined Autonomy, Resolving the tension between flexibility and control. ECM Insightsand Best Practicesfrom the Laserficheteam Tue, 16 Sep 2014.

22. Maksimović, G., Pejanović, R., Njegovan, Z. (2013). Ekonomika poljoprivrede (978-86-80737-35-5). Novograf, Vrnjačka Banja.

23. Milisavljević, M. (2012). Strategijski menadžment (978-86-403-1250-9). CID Ekonomskog fakulteta, Beograd.

24. Chen, M. H., Chang, Y. Y. (2013). The impacts of human capital in enhancing new venture's performance. Journal of Knowledge-based Innovation in China, Vol. 5, No. 2, pp. 146-168.

25. Njegovan, Z., Pejanović, R. (2015). Planiranje i upravljanje ruralnim razvojem u Podunavlju Srbije (978-86-7520-362-9). Feljton, Novi Sad.

26. Pejanović, R. (2011). Ekonomika, menadžment i organizacija (978-86-7520-228-8). Poljoprivredni fakultet, Novi Sad.

27. Pejanović, R., Njegovan, Z. (2013). Ekonomika poljoprivrede, agrarna politika $i$ ruralni razvoj (978-86-82923-11-4). Novograf, Vrnjačka Banja.

28. Pejanović, R. (2012). Uvod u mikroekonomiju, Poljoprivredni fakultet, Novi Sad.

29. Pejanović, R. (2001). Značaj i uloga ljudskog kapitala u agrarnoj ekonomiji. 
Savremeni farmer, Vol. 7, pp. $17-18$.

30. Pejanović, R. (2013). Ogledi iz agrarne i ruralne ekonomije (978-86-7520-259-2). Poljoprivredni fakultet, Novi Sad.

31. Saragih, S. (2011). The effects of job autonomy on work outcomes: self efficacy as an intervening variable. International Research Journal of Business Studies. Vol. 4, No.3, pp. 203-215.

32. Su, S., Baird, K., Schoch, H. (2015). Management control system effectiveness: The association between types of controls with employee organizational commitment across organisational life cycle stages. Pacific Accounting Review, Vol. 27, No. 1, pp. 28 - 50.

33. Van Mierlo, H., Rutte, C., Vermunt, J., Kompier, M., Dooreward, J. (2006). Individual autonomy in work teams: The role of team autonomy, self-efficacy, and social support. European Journal of Work and Organizational Psychology, Vol. 15, No. 3, pp. 281-299.

34. Vanderfeesten, I., Reijers, H. A. (2006). How to increase work autonomy in workflow management systems? Management Research News, Vol. 29, No. 10, pp. 652-665.

35. Wheatley, D. (2017). Autonomy in Paid Work and Employee Subjective WellBeing. Work and Occupations, Vol. 44, No. 3, pp. 296-328.

36. Wrzesniewski, A., Dutton, J. (2001). Crafting a job: revisioning employees as active crafters of their work. Academy of Management Review, Vol. 26, pp. 179-201. 


\title{
NEKI IZAZOVI MENADŽMENTA U PREHRAMBENIM KOMPANIJAMA U REPUBLICI SRBIJI I BOSNI I HERCEGOVINI
}

\author{
Filip Đoković, Radovan Pejanović, ${ }^{7}$ Jelena Đorđević Boljanovićc ${ }^{9}$ Gordana \\ Dobrijević $^{10}$, Miloš Mojsilović ${ }^{11}$, Đurđica Jojić Novaković ${ }^{12}$
}

\begin{abstract}
Sažetak
U najširem smislu, menadžment je poslovna filozofija. Međutim, u užem smislu, termin ima vrlo specifično značenje, što je predmet ovog istraživanja. Autori su odabrali aktuelno pitanje u kontroli, jednoj od pet funkcija upravljanja. Autonomija je na poslu, determinanta kontrole zaposlenih, koja je u velikoj meri istraživana u prehrambenim kompanijama u Republici Srbiji i Bosni i Hercegovini.

Kontrola zaposlenih, njihov učinak i rezultati predstavljaju veliki izazov menadžmenta u procesu poboljšanja efikasnosti upravljanja ljudskim resursima kompanije, poslovnog učinka i konkurentnosti. Ključno pitanje je kako dizajnirati sistem kontrole u kompanijama koje su uključene u istraživanje, ali nije lako ni definisati odgovarajuću ulogu za posebnu vrstu kontrole - kontrolu zaposlenih, njihov učinak i rezultate - $s$ obzirom na kulturu znanja, inovacije i kreativnost, koji su sve značajniji u poboljšanju ekonomske efikasnosti i konkurentnosti. Druga svrha istraživanja je i da otkriju razlike u autonomiji kao determinantu kontrole zaposlenih u ovim kompanijama ili, preciznije, da saznaju u kojoj meri autonomija među menadžerima može uticati na kreativnost, inovativnost i poslovne performanse.
\end{abstract}

7 Dr Fillip Đoković, docent, Singidunum Univerzitet, Fakultet zdravstvenih, pravnih i poslovnih studija, Železnička br. 5, tel: +381 14292 610, E-mail: fdjokovic@singidunum.ac.rs

8 Dr Radovan Pejanović, redovni profesor, Universitet Novi Sad, Poljoprivredni fakultet, Trg Dositeja Obradovića br. 8, 21000 Novi Sad, tel: +381 216350 622, E-mail: pejanovic@uns.ac.rs

9 Dr Jelena Đorđević Boljanović, vanredni profesor, Singidunum Univerzitet, Poslovni fakultet, Kumodraška br. 261a, tel.: +381 113094 094, E-mail: jboljanovic@singidunum.ac.rs

10 Dr Gordana Dobrijević, vanredni professor, Singidunum Univerzitet, Poslovni fakultet, Kumodraška br. 261a, tel: +381 113094 094, E-mail: gdobrijevic@singidunum.ac.rs

11 Miloš Mojsilović, M.A., Ipsos Strategic Marketing, Gavrila Principa br. 8, tel: +381 11 3284 075, E-mail: mojsilovic.milos@gmail.com

12 Đurđica Jojić Novaković, doktorand, Fakultet za hotelijerstvo i turizam, Univerzitet Kragujevac, Vrnjačka Banja, Vojvođanska 5A, 36210 Vrnjačka Banja, tel +381 603873 422, E-mail: djurdjica.jojic@gmail.com 